\title{
Gluconobacter asaii Mason and Claus 1989 is a junior subjective synonym of Gluconobacter cerinus Yamada and Akita 1984
}

Laboratory of General and Applied Microbiology, Department of Applied Biology and Chemistry, Faculty of Applied Bioscience, Tokyo University of Agriculture, 1-1-1 Sakuragaoka, Setagaya-ku, Tokyo 156-8502, Japan

\author{
Kazushige Katsura, Yuzo Yamada, Tai Uchimura and Kazuo Komagata
}

Author for correspondence: Kazushige Katsura. Tel: +8135477 2328. Fax: +81334276435. e-mail:katsurak@d2.dion.ne.jp

Five strains received as Gluconobacter cerinus and Gluconobacter asaii were examined for DNA base composition, DNA-DNA similarity, 16S rRNA gene sequences and phenotypic characteristics, including acid production from ethanol, growth on L-arabitol and meso-ribitol and requirement for nicotinic acid. The five strains showed DNA base compositions ranging from 54 to $56 \mathrm{~mol} \%$ G+C. G. cerinus IFO $3267^{\top}$ and IAM 1832 and G. asaii IFO $3276^{\top}$ and IFO 3275 showed high levels of DNA-DNA similarity (70-100\%) between each other and low values of DNA-DNA similarity (16-35\%) to Gluconobacter frateurii IFO $3264^{\top}$ and Gluconobacter oxydans IFO $14819^{\top}$. G. cerinus IFO $3267^{\top}$ and G. asaii IFO $3276^{\top}$ were located at an identical position in a phylogenetic tree deduced from 16S rRNA gene sequences. Two G. cerinus strains and two G. asaii strains did not require nicotinic acid for growth and did not grow on L-arabitol or meso-ribitol. G. cerinus IAM 1832 did not produce acid and required nicotinic acid and/or other growth factors. G. asaii IFO 3265 showed a high degree of DNA-DNA similarity (97\%) to G. frateurii IFO $3264^{\top}$ and low similarity values (each $32 \%$ ) to G. cerinus IFO $3267^{\top}$ and G. asaii IFO $3276^{\top}$. This strain did not require nicotinic acid and grew well on L-arabitol and meso-ribitol. Therefore, G. asaii IFO 3265 was reclassified as $G$. frateurii. The results obtained revealed a synonymous relationship between $G$. cerinus and $G$. asaii. G. asaii is a junior subjective synonym of $G$. cerinus because $G$. cerinus has priority over $\mathbf{G}$. asaii.

Keywords: Gluconobacter cerinus, Gluconobacter asaii, acetic acid bacteria, Acetobacteraceae, Proteobacteria

\section{INTRODUCTION}

The species Gluconobacter cerinus was first proposed by Asai \& Shoda (1958) but was not included in the Approved Lists of Bacterial Names (Skerman et al., 1980). This species was revived as the second species of the genus Gluconobacter on the basis of DNA base composition, DNA-DNA similarity and electrophoretic patterns of enzymes (Yamada \& Akita, 1984a) and was subsequently validated (Yamada \& Akita, 1984b). Strains assigned to G. cerinus were characterized by low values for DNA G $+\mathrm{C}$ content

Published online ahead of print on 7 June 2002 as DOI 10.1099/ ijs.0.02093-0.

The DDBJ accession numbers for the 16S rRNA gene sequences of Gluconobacter cerinus IFO $3267^{\top}$ and IAM 1832 and Gluconobacter asaii IFO $3276^{\top}$ are $A B 063286, A B 063288$ and $A B 063287$.
(Yamada and Akita, 1984a) and were included in phenon $\mathrm{A}$ on the basis of numerical analysis of phenotypic features and in cluster $\mathrm{A}^{\prime}$ on the basis of the electrophoretic protein pattern (Gosselé et al., 1983). In contrast, strains assigned to Gluconobacter oxydans, the type species of the genus Gluconobacter, were characterized by high values for DNA $G+C$ content (Yamada \& Akita, 1984a), and were included in phenon $\mathrm{B}$ on the basis of numerical analysis of phenotypic features and in cluster $\mathrm{B}^{\prime}$ on the basis of the electrophoretic protein pattern (Gosselé et al., 1983).

Micales et al. (1985) reported the division of strains assigned to the genus Gluconobacter into three homology groups according to DNA-DNA similarity. Later, Mason \& Claus (1989) introduced three species, G. oxydans, Gluconobacter frateurii and Gluconobacter asaii, respectively, for homology groups I, II and III of Micales et al. (1985). However, it is worth noting that 
G. asaii was described without data on DNA-DNA similarity between $G$. asaii IFO $3276^{\mathrm{T}}$ and G. cerinus IFO $3267^{\mathrm{T}}$. These homology groups should be reclassified, since the DNA-DNA hybridization data reported by Micales et al. (1985) did not correspond to the modern concept of bacterial species recommended by Wayne et al. (1987). Recently, Yamada et al. (1999) and Tanaka et al. (1999) reported high values for DNA-DNA similarity between the type strains of $G$. cerinus and $G$. asaii and suggested a synonymous relationship between the two species. However, neither Yamada et al. (1999) nor Tanaka et al. (1999) mentioned which of the species has priority.

This study aims to re-examine the homogeneity of strains received as G. cerinus and those received as G. asaii on the basis of DNA-DNA similarity, 16S rRNA gene sequences and phenotypic characteristics and to describe the synonymous relationship between G. cerinus and $G$. asaii and the priority of G. cerinus over $G$. asaii in bacterial nomenclature.

\section{METHODS}

Bacterial strains. The five Gluconobacter strains studied were obtained from culture collections, as shown in Table 1. G. cerinus IAM 1832 was examined, since this strain was reported not to produce acetic acid from ethanol (Asai et al., 1964; Gosselé et al., 1983). An additional strain, IFO 3297, received as Acetobacter sp., was also used, since Micales et al. (1985) had reported two colony types for this strain and had identified both as Gluconobacter sp. G. oxydans IFO $14819^{\mathrm{T}}$ and $G$. frateurii IFO $3264^{\mathrm{T}}$ were used as reference strains. These bacterial strains were maintained on a basal medium composed of $2.0 \% \mathrm{D}$-glucose, $1.0 \%$ yeast extract, $0.7 \% \mathrm{CaCO}_{3}$ and $1.5 \%$ agar (all by weight).

Acid production from ethanol. Acid production from ethanol was tested by using the colour change of bromocresol purple in a test medium (Yamada et al., 1976).

Oxidation of acetate and lactate. Testing of the oxidation of lactate and acetate to $\mathrm{CO}_{2}$ and $\mathrm{H}_{2} \mathrm{O}$ was carried out using a method described previously (Asai et al., 1964; Yamada et al., 1999, 2000; Katsura et al., 2001).

Quinone homologues. Isoprenoid quinones were extracted from bacterial cells and purified by the method of Yamada et al. (1969). Ubiquinone isoprenologues were determined quantitatively by reverse-phase HPLC (Tamaoka et al., 1983).

DNA base composition and DNA-DNA similarity. Bacterial DNAs were extracted and purified by the modified method of Marmur (1961) (Saito \& Miura, 1963). The DNA base composition was determined by reverse-phase HPLC (Tamaoka \& Komagata, 1984). DNA-DNA similarity was determined by using a microdilution-well technique with photobiotin for labelling (Ezaki et al., 1989). Isolated, singlestranded and labelled DNAs were hybridized with DNAs from test strains in $2 \times$ SSC and $50 \%$ formamide at 46.9 or $49 \cdot 0{ }^{\circ} \mathrm{C}$ for $2-3 \mathrm{~h}$.

Phylogenetic analysis. The $16 \mathrm{~S}$ rRNA gene sequences were determined as described previously (Yamada et al., 2000; Katsura et al., 2001). The sequence data obtained were aligned with the program CLUSTAL W version 1.8 (Thompson et al., 1994). Distance matrices for the aligned sequences (1377 bases) were calculated by using Kimura's twoparameter method (Kimura, 1980) and a phylogenetic tree was constructed by the neighbour-joining method (Saitou \& Nei, 1987). The robustness of individual branches was estimated by bootstrapping with 1000 replicates (Felsenstein, 1985).

Growth on pentitols. Growth on L-arabitol and meso-ribitol was tested by the use of a medium containing $0.2 \%$ pentitol (L-arabitol or meso-ribitol), $0.3 \%$ yeast extract (Difco), $0 \cdot 1 \%\left(\mathrm{NH}_{4}\right)_{2} \mathrm{SO}_{4}, 0.01 \% \mathrm{~K}_{2} \mathrm{HPO}_{4}, 0.09 \% \mathrm{KH}_{2} \mathrm{PO}_{4}, 0.025 \%$ $\mathrm{MgSO}_{4} \cdot 7 \mathrm{H}_{2} \mathrm{O}$ and $0 \cdot 0005 \% \mathrm{FeCl}_{3} \cdot 6 \mathrm{H}_{2} \mathrm{O}$ (all components added by weight).

Requirement for nicotinic acid. Growth of strains with and without nicotinic acid was tested by using a medium containing three carbon sources $[0.5 \%(\mathrm{w} / \mathrm{v})$ each for D-glucose, D-mannitol and glycerol], $0.5 \%$ vitamin-free Casamino acids (Difco) (w/v), $0 \cdot 1 \%(\mathrm{w} / \mathrm{v})\left(\mathrm{NH}_{4}\right)_{2} \mathrm{SO}_{4}$, $100 \mathrm{mg} \mathrm{K}{ }_{2} \mathrm{HPO}_{4}, 900 \mathrm{mg} \mathrm{KH} \mathrm{PO}_{4}, 250 \mathrm{mg} \mathrm{MgSO}_{4} .7 \mathrm{H}_{2} \mathrm{O}$ and $5 \cdot 0 \mathrm{mg} \mathrm{FeCl}_{3} \cdot 6 \mathrm{H}_{2} \mathrm{O} \mathrm{1^{-1 }}$ and vitamins. Vitamins were supplemented in the test media at the following final concentrations $\left(\mathrm{mg} \mathrm{l}^{-1}\right)$ with or without $1.5 \mathrm{mg}$ nicotinic acid $1^{-1}$ : pyridoxal hydrochloride, $1 \cdot 5$; riboflavin, $1 \cdot 5$; thiamin, $1 \cdot 0$; pantothenic acid, $1 \cdot 0$; $p$-aminobenzoic acid, $1 \cdot 0$; biotin, 1.0. A loopful of cells grown on the basal medium was inoculated into the test medium containing nicotinic acid. The inoculated medium was incubated at $30{ }^{\circ} \mathrm{C}$ for 2 days with shaking and the culture broth was then inoculated into two media, with or without nicotinic acid. Growth was judged to be positive when the micro-organisms grew well after two passages with the medium lacking nicotinic acid.

Table 1. Correspondence of strains used in this study and other studies

\begin{tabular}{|c|c|c|c|c|c|}
\hline \multirow[t]{2}{*}{ Strain } & \multirow[t]{2}{*}{ Received as: } & \multicolumn{4}{|c|}{ Used by: } \\
\hline & & This study & Gosselé et al. (1983) & Yamada \& Akita (1984a) & Micales et al. (1985) \\
\hline IFO $3267^{\mathrm{T}}$ & G. cerinus & + & + & + & - \\
\hline IAM 1832 & G. cerinus & + & + & + & - \\
\hline IFO $3276^{\mathrm{T}}$ & G. asaii & + & + & + & + \\
\hline IFO 3275 & G. asaii & + & - & + & + \\
\hline IFO 3265 & G. asaii & + & + & + & + \\
\hline IFO $3264^{\mathrm{T}}$ & G. frateurii & + & + & + & + \\
\hline IFO $14819^{\mathrm{T}}$ & G. oxydans & + & + & + & + \\
\hline IFO 3297 & Acetobacter sp. & + & - & - & + \\
\hline
\end{tabular}




\section{RESULTS AND DISCUSSION}

\section{Phylogenetic analysis}

The sequences of $G$. cerinus IFO $3267^{\mathrm{T}}$ and $G$. asaii IFO $3276^{\mathrm{T}}$ were identical to each other in this study and $G$. cerinus IFO $3267^{\mathrm{T}}$ and IAM 1832 and $G$. asaii IFO $3276^{\mathrm{T}}$ were located at an identical position in the phylogenetic tree in Fig. 1. The positions of the type strains differed from those in the tree of Sievers et al. (1995). Discrepancies were found in the sequence of G. asaii IFO $3276^{\mathrm{T}}$ between the data from this study (accession no. AB063287) and those reported by Sievers et al. (1995) (accession no. X80165). These were assumed to be due to the misreading of 17 bases, corresponding to $1 \cdot 2 \%$ of the complete sequence of $16 \mathrm{~S}$ rRNA. Thirteen bases, at positions $65,110,318$, 371, 403, 537, 618, 634, 948, 1069, 1083, 1092 and 1372 (Escherichia coli numbering system, accession no. V00348; Brosius et al., 1981), in the sequence of

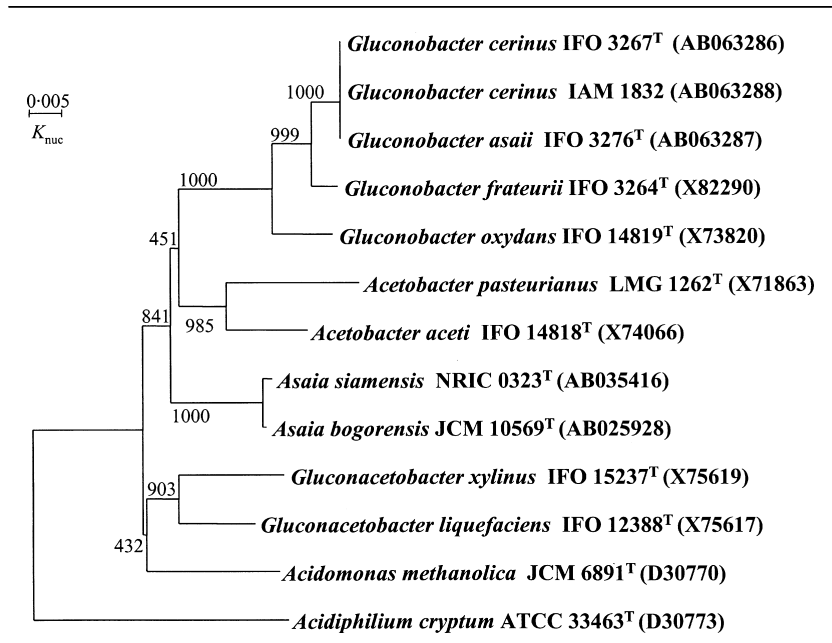

Fig. 1. Phylogenetic relationships of Gluconobacter species, based on 16S rRNA gene sequences. Acidiphilium cryptum ATCC $33463^{\top}$ was used as an outgroup. Numerals at nodes indicate bootstrap values derived from 1000 replications (Felsenstein, 1985).
G. asaii (accession no. X80165) should be read respectively as C, C, G, A, C, G, C, C, C, C, T, A and T. The bases at the above positions are commonly found in the type strains of the type species of the genera Acetobacter, Gluconobacter, Gluconacetobacter, Acidomonas and Asaia along with the type strain of Acidiphilium cryptum ( $\alpha$-Proteobacteria) (respectively accession nos X74066, X73820, X75617, D30770, AB025928 and D30773). However, the 13 bases at the above-mentioned positions were read by Sievers et al. (1995) as T, T, A, T, G, C, G, G, G, G, C, G and C. Four other bases, at positions 580, 589, 629 and 645, were read as $\mathrm{C}, \mathrm{T}, \mathrm{A}$ and $\mathrm{C}$ in this study. In contrast, Sievers et al. (1995) recognized them as G, G, G and G.

\section{Quinone homologues}

All the strains received as Gluconobacter species had Q-10 as the major quinone and Acetobacter sp. IFO 3297 had Q-9 (Table 3).

\section{DNA base compositions and DNA-DNA similarity}

The $\mathrm{G}+\mathrm{C}$ contents of the DNA of the two $G$. cerinus strains and three $G$. asaii strains ranged from 54 to $56 \mathrm{~mol} \%$ (Table 2).

Values for DNA-DNA similarity ranged from 70 to $100 \%$ among four strains received as $G$. cerinus and $G$. asaii when DNAs of $G$. cerinus IFO $3267^{\mathrm{T}}$ and $G$. asaii IFO $3276^{\mathrm{T}}$ were used as probes (Table 2). G. asaii IFO 3265 showed a high degree of DNA-DNA similarity $(97 \%)$ to $G$. frateurii IFO $3264^{\mathrm{T}}$ and low similarity (each $32 \%$ ) to $G$. cerinus IFO $3267^{\mathrm{T}}$ and $G$. asaii IFO $3276^{\mathrm{T}}$.

\section{Growth on pentitols}

G. cerinus IFO $3267^{\mathrm{T}}$ and IAM 1832, G. asaii IFO $3276^{\mathrm{T}}$ and IFO 3275 and $G$. oxydans IFO $14819^{\mathrm{T}}$ grew neither on L-arabitol nor on meso-ribitol, but $G$. asaii IFO 3265 and $G$. frateurii IFO $3264^{\mathrm{T}}$ grew well on these pentitols (Table 3).

Table 2. DNA base compositions and values for DNA-DNA similarity among $G$. cerinus and $G$. asaii strains

\begin{tabular}{|c|c|c|c|c|c|c|}
\hline \multirow[t]{2}{*}{ Strain } & \multirow[t]{2}{*}{ Received as: } & \multirow{2}{*}{$\begin{array}{c}\text { DNA G }+ \text { C content } \\
(\mathrm{mol} \%)\end{array}$} & \multicolumn{4}{|c|}{ Relative binding (\%) to DNA from: } \\
\hline & & & 1 & 3 & 6 & 7 \\
\hline 1. IFO $3267^{\mathrm{T}}$ & G. cerinus & 56 & 100 & 87 & 33 & 27 \\
\hline 2. IAM 1832 & G. cerinus & 55 & 83 & NT & 35 & 19 \\
\hline 3. IFO $3276^{\mathrm{T}}$ & G. asaii & 55 & 77 & 100 & 27 & 16 \\
\hline 4. IFO 3275 & G. asaii & 54 & 70 & 86 & 26 & 18 \\
\hline 5. IFO 3265 & G. asaii & 56 & 32 & 32 & 97 & 35 \\
\hline 6. IFO $3264^{\mathrm{T}}$ & G. frateurii & 55 & 31 & 36 & 100 & 29 \\
\hline 7. IFO $14819^{\mathrm{T}}$ & G. oxydans & 60 & 17 & 10 & 22 & 100 \\
\hline
\end{tabular}

NT, Not tested. 
Table 3. Phenotypic characteristics of $G$. cerinus and $G$. asaii strains

\begin{tabular}{|c|c|c|c|c|c|c|c|c|}
\hline \multirow[t]{2}{*}{ Strain } & \multirow[t]{2}{*}{ Received as: } & \multicolumn{2}{|c|}{ Growth on: } & \multirow{2}{*}{$\begin{array}{c}\text { Growth without } \\
\text { nicotinic acid }\end{array}$} & \multicolumn{2}{|c|}{ Oxidation of: } & \multirow{2}{*}{$\begin{array}{l}\text { Major } \\
\text { quinone }\end{array}$} & \multirow[t]{2}{*}{ Identified as: } \\
\hline & & meso-Ribitol & L-Arabitol & & Acetate & Lactate & & \\
\hline IFO $3267^{\mathrm{T}}$ & G. cerinus & - & - & + & - & - & Q-10 & G. cerinus \\
\hline IAM 1832 & G. cerinus & - & - & $-*$ & - & - & Q-10† & G. cerinus \\
\hline IFO $3276^{\mathrm{T}}$ & G. asaii & - & - & + & - & - & Q-10 & G. cerinus \\
\hline IFO 3275 & G. asaii & - & - & + & - & - & Q-10† & G. cerinus \\
\hline IFO 3265 & G. asaii & + & + & + & - & - & Q-10† & G. frateurii \\
\hline IFO $3264^{\mathrm{T}}$ & G. frateurii & + & + & + & - & - & Q-10 & G. frateurii \\
\hline IFO $14819^{T}$ & G. oxydans & - & - & - & - & - & Q-10 & G. oxydans \\
\hline IFO $3297 \$$ & Acetobacter sp. & NT & NT & NT & - & + & Q-9 & Acetobacter sp. \\
\hline
\end{tabular}

* Other growth factors are required by this strain.

$\uparrow$ Data from Yamada \& Akita (1984a).

\$ Mason \& Claus (1989) classified strain IFO $3297 b$ as G. asaii.

NT, Not tested.

\section{Requirement for nicotinic acid}

G. cerinus IFO $3267^{\mathrm{T}}$, G. asaii IFO $3276^{\mathrm{T}}$, IFO 3275 and IFO 3265 and G. frateurii IFO $3264^{\mathrm{T}}$ did not require nicotinic acid for growth, whereas $G$. oxydans IFO $14819^{\mathrm{T}}$ required nicotinic acid (Table 3 ). G. cerinus IAM 1832 did not grow with nicotinic acid and was assumed to require other growth factors, as suggested by Gosselé et al. (1983). The requirement for nicotinic acid is employed for the differentiation of members of G. oxydans from those of other species in the genus Gluconobacter (Yamada \& Akita, 1984a; Mason \& Claus, 1989). However, an exception should be recognized in the case of $G$. cerinus IAM 1832, which did not grow with nicotinic acid.

\section{Acid production from ethanol}

Strain IAM 1832 did not produce acid from ethanol, as reported by Asai et al. (1964) and Gosselé et al. (1983).

\section{Oxidation of acetate and lactate}

None of the Gluconobacter strains tested oxidized either acetate or lactate. Acetobacter sp. IFO 3297 oxidized lactate but not acetate (Table 3).

\section{Synonymous relationship between G. cerinus and G. asaii}

As mentioned above, the type strains of G. cerinus and G. asaii had high values of DNA-DNA similarity with each other. However, Sievers et al. (1995) reported that the type strains of G. cerinus and G. asaii were not located close to each other, and a significant difference was found in their phylogenetic trees. Accordingly, a question arose as to whether the locations of the two species are correct. Therefore, the sequences of G. cerinus IFO $3267^{\mathrm{T}}$ and G. asaii IFO $3276^{\mathrm{T}}$ were reinvestigated in this study. As mentioned above, the $16 \mathrm{~S}$ rRNA sequences of these strains were identical.
Yamada \& Akita (1984a) revived G. cerinus, with the type strain IFO $3267^{\mathrm{T}}$. Micales et al. (1985) reported three homology groups in the genus Gluconobacter, but they did not mention the DNA-DNA similarity between G. cerinus IFO $3267^{\mathrm{T}}$ and each of members of homology group III. Four years later, Mason \& Claus (1989) introduced a novel species, G. asaii, for homology group III of Micales et al. (1985). However, they did not determine DNA-DNA similarity between the type strains of G. asaii and G. cerinus. Mason \& Claus (1989) should have determined the DNA-DNA similarity between the type strains of $G$. asaii and G. cerinus because the type strain of $G$. cerinus was available at that time. Furthermore, Mason \& Claus (1989) did not present growth data on L-arabitol and meso-ribitol for G. cerinus IFO $3267^{\mathrm{T}}$.

From the viewpoint of modern bacterial systematics (Wayne et al., 1987), bacterial species established without data on DNA-DNA similarity between the type strains of species in that genus should be reexamined. The present study clearly demonstrates that all of the strains received as $G$. asaii, except for strain IFO 3265, were reidentified as G. cerinus on the basis of DNA-DNA similarity, 16S rRNA gene sequence and phenotypic characteristics. It is clear from the results obtained in this study that $G$. cerinus and $G$. asaii are synonymous. G. cerinus Yamada and Akita 1984 has priority over G. asaii Mason and Claus 1989, and $G$. asaii is therefore a junior subjective synonym of G. cerinus.

\section{G. cerinus IAM 1832}

Asai et al. (1964) and Gosselé et al. (1983) reported that this strain did not produce acid from ethanol. This was confirmed in this study. Interestingly, the nutritional requirements of this strain were found to be rather complex compared with other $G$. cerinus strains. 


\section{Segregation of colony types}

G. asaii IFO $3276^{\mathrm{T}}$. G. asaii IFO $3276^{\mathrm{T}}$ showed two colony types in this study, a large type and a small type, but the two colony types were identical in having high values for DNA-DNA similarity (data not shown). The same result was obtained by Mason \& Claus (1989).

G. asaii IFO 3275. Micales et al. (1985) reported two colony types for G. asaii IFO 3275. Furthermore, they placed strain IFO $3275 a$ in homology group I $(=G$. oxydans) and strain IFO $3275 b$ in homology group III (=G. asaii) (Micales et al., 1985; Mason \& Claus, 1989). In this study, only a single colony type was recognized for strain IFO 3275 received from the Institute for Fermentation (IFO), Osaka, Japan, and this strain was identified as $G$. cerinus on the basis of DNA $\mathrm{G}+\mathrm{C}$ content, DNA-DNA similarity and growth on pentitols.

Acetobacter sp. IFO 3297. Micales et al. (1985) recognized two colony types for Acetobacter sp. IFO 3297, and strains with different colony types were identified as Gluconobacter species. Strain IFO $3297 a$ was placed in homology group III (= G. asaii) and strain IFO $3297 b$ was placed in homology group I $(=G$. oxydans $)$ (Micales et al., 1985; Mason \& Claus, 1989). In this study, a single colony type was found for Acetobacter sp. IFO 3297 received from the IFO, and the strain was reidentified as an Acetobacter species on the basis of the presence of Q-9 and the oxidation of lactate. This strain was in fact located within a cluster composed of Acetobacter pasteurianus and Acetobacter pomorum in a phylogenetic tree based on the partial 16S rRNA gene sequence (positions 62-611, 494 bases; data not shown). It is interesting to note that this strain oxidized lactate but not acetate. We tried to obtain the same strains employed by Micales et al. (1985) and Mason \& Claus (1989), but their strains were not available.

\section{Reclassification of G. asaii IFO 3265}

Micales et al. (1985) placed G. asaii IFO 3265 in homology group III, and Mason \& Claus (1989) classified it as $G$. asaii. However, this strain showed a very high value for DNA-DNA similarity $(97 \%)$ with G. frateurii IFO $3264^{\mathrm{T}}$ and grew well on L-arabitol and meso-ribitol, as did $G$. frateurii IFO $3264^{\mathrm{T}}$. The data obtained in this study indicate that G. asaii IFO 3265 should be reclassified as $G$. frateurii.

\section{Emended description of Gluconobacter cerinus Yamada and Akita 1984}

Junior subjective synonym: Gluconobacter asaii Mason and Claus 1989.

The description of Gluconobacter cerinus is based on the original description (Yamada \& Akita, 1984a), with the additional information that there is no growth on L-arabitol or meso-ribitol. The type strain of G. cerinus is IFO $3267^{\mathrm{T}}$.

\section{ACKNOWLEDGEMENTS}

The authors wish to thank the Institute for Fermentation, Osaka, Japan, and IAM Culture Collection, University of Tokyo, Tokyo, Japan, for supplying the type and reference strains.

\section{REFERENCES}

Asai, T. \& Shoda, K. (1958). The taxonomy of Acetobacter and allied oxidative bacteria. J Gen Appl Microbiol 4, 289-311.

Asai, T., lizuka, H. \& Komagata, K. (1964). The flagellation and taxonomy of genera Gluconobacter and Acetobacter with reference to the existence of intermediate strains. J Gen Appl Microbiol 10, 95-126.

Brosius, J., Dull, T. J., Sleeter, D. D. \& Noller, H. F. (1981). Gene organization and primary structure of a ribosomal RNA operon from Escherichia coli. J Mol Biol 148, 107-127.

Ezaki, T., Hashimoto, Y. \& Yabuuchi, E. (1989). Fluorometric deoxyribonucleic acid-deoxyribonucleic acid hybridization in microdilution wells as an alternative to membrane filter hybridization in which radioisotopes are used to determine genetic relatedness among bacterial strains. Int J Syst Bacteriol 39, 224-229.

Felsenstein, J. (1985). Confidence limits on phylogenies: an approach using the bootstrap. Evolution 39, 783-791.

Gosselé, F., Swings, J., Kersters, K. \& De Ley, J. (1983). Numerical analysis of phenotypic features and protein gel electropherograms of Gluconobacter Asai 1935 emend. mut. char. Asai, Iizuka, and Komagata 1964. Int J Syst Bacteriol 33, 65-81.

Katsura, K., Kawasaki, H., Potacharoen, W., Saono, S., Seki, T., Yamada, Y., Uchimura, T. \& Komagata, K. (2001). Asaia siamensis sp. nov., an acetic acid bacterium in the $\alpha$-Proteobacteria. Int J Syst Evol Microbiol 51, 559-563.

Kimura, M. (1980). A simple method for estimating evolutionary rates of base substitutions through comparative studies of nucleotide sequences. J Mol Evol 16, 111-120.

Marmur, J. (1961). A procedure for isolation of deoxyribonucleic acid from micro-organisms. J Mol Biol 3, 208-218.

Mason, L. M. \& Claus, G. W. (1989). Phenotypic characteristics correlated with deoxyribonucleic acid sequence similarities for three species of Gluconobacter : G. oxydans (Henneberg 1897) De Ley 1961, G. frateurii sp. nov., and G. asaii sp. nov. Int J Syst Bacteriol 39, 174-184.

Micales, B. K., Johnson, J. L. \& Claus, G. W. (1985). Deoxyribonucleic acid homologies among organisms in the genus Gluconobacter. Int J Syst Bacteriol 35, 79-85.

Saito, H. \& Miura, K. (1963). Preparation of transforming deoxyribonucleic acid by phenol treatment. Biochim Biophys Acta 72, 619-629.

Saitou, N. \& Nei, M. (1987). The neighbor-joining method: a new method for reconstructing phylogenetic trees. Mol Biol Evol 4, 406-425.

Sievers, M., Gaberthüel, C., Boesch, C., Ludwig, W. \& Teuber, M. (1995). Phylogenetic position of Gluconobacter species as a coherent cluster separated from all Acetobacter species on the basis of $16 \mathrm{~S}$ ribosomal RNA sequences. FEMS Microbiol Lett 126, 123-126.

Skerman, V. B. D., McGowan, V. \& Sneath, P. H. A. (editors) (1980). Approved lists of bacterial names. Int $J$ Syst Bacteriol 30, 225-420.

Tamaoka, J. \& Komagata, K. (1984). Determination of DNA base composition by reversed phase high performance liquid chromatography. FEMS Microbiol Lett 25, 125-128.

Tamaoka, J., Katayama-Fujimura, Y. \& Kuraishi, H. (1983). Analysis of bacterial menaquinone mixtures by high-performance liquid chromatography. J Appl Bacteriol 54, 31-36.

Tanaka, M., Murakami, S., Shinke, R. \& Aoki, K. (1999). Reclassification of the strains with low $\mathrm{G}+\mathrm{C}$ contents of DNA belonging to the genus Gluconobacter Asai 1935 (Acetobacteraceae). Biosci Biotechnol Biochem 63, 989-992.

Thompson, J. D., Higgins, D. G. \& Gibson, T. J. (1994). CLUSTAL W: improving the sensitivity progressive multiple sequence alignment 
through sequence weighting, position-specific gap penalties and weight matrix choice. Nucleic Acids Res 22, 4673-4680.

Wayne, L. G., Brenner, D. J., Colwell, R. R. \& 9 other authors (1987). International Committee on Systematic Bacteriology. Report of the ad hoc committee on reconciliation of approaches to bacterial systematics. Int J Syst Bacteriol 37, 463-464.

Yamada, Y. \& Akita, M. (1984a). An electrophoretic comparison of enzymes in strains of Gluconobacter species. J Gen Appl Microbiol 30, 115-126.

Yamada, Y. \& Akita, M. (1984b). Gluconobacter cerinus. In Validation of the Publication of New Names and New Combinations Previously Effectively Published Outside the IJSB, List no. 16. Int J Syst Bacteriol 34, 503-504.

Yamada, Y., Aida, K. \& Uemura, T. (1969). Enzymatic studies on the oxidation of sugar and sugar alcohol. V. Ubiquinone of acetic acid bacteria and its relation to classification of Gluconobacter and Acetobacter, especially of the so-called intermediate strains. J Gen Appl Microbiol 15, 186-196.

Yamada, Y., Okada, Y. \& Kondo, K. (1976). Isolation and characterization of 'polarly flagellated intermediate strains' in acetic acid bacteria. J Gen Appl Microbiol 22, 237-245.

Yamada, Y., Hosono, R., Lisdiyanti, P., Widyastuti, Y., Saono, S., Uchimura, T. \& Komagata, K. (1999). Identification of acetic acid bacteria isolated from Indonesian sources, especially of isolates classified in the genus Gluconobacter. J Gen Appl Microbiol 45, 23-28.

Yamada, Y., Katsura, K., Kawasaki, H., Widyastuti, Y., Saono, S., Seki, T., Uchimura, T. \& Komagata, K. (2000). Asaia bogorensis gen. nov., sp. nov., an unusual acetic acid bacterium in the $\alpha$-Proteobacteria. Int J Syst Evol Microbiol 50, 823-829. 